\title{
Article \\ Understanding the Adoption of Incentivized Word-of-Mouth in the Online Environment
}

\author{
Bogdan Anastasiei ${ }^{1}$, Nicoleta Dospinescu ${ }^{1}$ and Octavian Dospinescu ${ }^{2, *(D)}$ \\ 1 Department of Management, Marketing and Business Administration, Faculty of Economics and Business \\ Administration, Alexandru Ioan Cuza University, 700506 Iaşi, Romania; \\ bogdan.anastasiei@feaa.uaic.ro (B.A.); dnicole@uaic.ro (N.D.) \\ 2 Department of Accounting, Business Information Systems and Statistics, Faculty of Economics and Business \\ Administration, Alexandru Ioan Cuza University, 700506 Iaşi, Romania \\ * Correspondence: doctav@uaic.ro
}

Citation: Anastasiei, B.; Dospinescu, N.; Dospinescu, O. Understanding the Adoption of Incentivized Word-of-Mouth in the Online Environment. J. Theor. Appl. Electron. Commer. Res. 2021, 16, 992-1007. https://doi.org/10.3390/jtaer160 40056

Academic Editor: María

Teresa Ballestar

Received: 6 January 2021

Accepted: 8 March 2021

Published: 10 March 2021

Publisher's Note: MDPI stays neutral with regard to jurisdictional claims in published maps and institutional affiliations.

Copyright: (C) 2021 by the authors. Licensee MDPI, Basel, Switzerland. This article is an open access article distributed under the terms and conditions of the Creative Commons Attribution (CC BY) license (https:// creativecommons.org/licenses/by/ $4.0 /)$.

\begin{abstract}
Nowadays, word-of-mouth is a very important component of e-commerce activity because consumers are very sensitive to other people's opinions. Depending on the companies' politics, these opinions can be incentivized or non-incentivized. One of the major dilemmas consists in establishing which kind of word-of-mouth has more influence on customers' perceptions. The purpose of this study is to assess the relationships between perceived argument quality (PAQ) and perceived source expertise (PSE), on the one hand, and electronic word-of-mouth adoption intention on the other hand, for an incentivized message compared to a non-incentivized message. We processed answers from two different random groups by using adapted PAQ and PSE inventories of questions. The constructs, latent variables and items were analyzed in IBM Amos software, and our findings confirm the hypotheses regarding the relationship between the attributes of the message (argument quality and source expertise) and message credibility. Additionally, we found a significant positive relationship between message credibility and electronic word-of-mouth adoption intention. Our research also explores the moderating role of the message type (incentivized vs. non-incentivized) in the relationships above, and we discovered that the message type significantly moderates the relationship between perceived argument quality and credibility, but the type of message does not moderate the relationship between message credibility and eWOM adoption intention.
\end{abstract}

Keywords: incentivized word-of-mouth; message type in e-commerce; e-WOM message credibility

\section{Introduction}

E-commerce is an increasingly important component of modern companies' business, regardless of their size. Consumers are very demanding, and they have access to a multitude of sources of information in the electronic environment. E-commerce generates a real ecosystem of data that circulates from one customer to another through various means and at asynchronous moments of time. Research in the field shows various relationships between the type of message, the type of consumer, the perceptions of potential customers and the influences on future purchasing decisions. Word-of-Mouth messages can be incentivized electronic Word-Of-Mouth (eWOM) or non-incentivized eWOM. Regarding incentivized eWOM, ref. [1] analyzed the effects of sponsorship disclosure on persuasion knowledge and electronic word of mouth in the context of Facebook. In the same vein, the study conducted by [2] revealed the impact of eWOM regarding the adoption of online opinions in online customer communities. The importance of our research is also justified by a recent article written by [3] which discusses motives and antecedents of electronic word of mouth communications in the context of consumers' online information adoption behavior. The role of the consumers' internet experience was also partially studied by [4] in order to discover the determinants of eWOM influence. 
Taking into consideration the previous research and scientific studies regarding eWOM and the associated issues, the purpose of our article is to determine whether incentivized messages play a role in the perceived trust of the customers to whom they are addressed, as well as in purchasing decisions.

To achieve this goal, we used a questionnaire-based methodology applied to a representative group of e-commerce consumers and we generated a construct based on latent variables. Through the scientific analysis of structural equation modeling, we identified the relationships between perceived argument quality, perceived source expertise, message credibility and eWOM adoption. The causal model provides an objective view of the influences between these latent variables and, moreover, highlights the moderating role of the message type in these relationships. Our research confirms some of the previous results from the literature and, as an element of novelty, demonstrates the role of moderator of the message type. As our results show, the message type significantly moderates the relationship between perceived argument's quality and credibility. The eWOM receiver will only trust a remunerated message if the transmitter proves that they are highly qualified to give recommendation for that product or service. On the other hand, non-incentivized messages can have a satisfactory level of credibility even if the perceived source expertise is relatively low.

The article is organized as follows: introduction, literature review, instrument and methodology, data analysis, discussion, limitations and further research, conclusions.

The literature review section details the main approaches already existing in terms of aspects related to perceived argument quality, perceived source expertise and message credibility. Following the analysis of the literature, we generated a total of six research hypotheses: three research hypotheses were built on the relationships between latent variables and three research hypotheses were built on moderation effects. The Instrument and Methodology section analytically presents the size and structure of the sample used in the research approach, as well as the detailed structure of the questionnaire on the main components: perceived argument quality (PAQ) and perceived source expertise (PSE). The Data Analysis chapter considers the verification of research hypotheses based on the proposed causal model. The Discussion section highlights the confirmatory results of the research as well as the original results that were demonstrated in the previous section of the paper. The article also presents limitations and further research possibilities, as well as general conclusions that contain managerial implications based on research results.

\section{Literature Review and Hypothesis Development}

\subsection{Perceived Argument Quality}

The relationship between argument quality and message credibility is addressed in the literature from various points of view and in various contexts. E-commerce transactions rely on trust perceived as a result of online message credibility.

Ref. [5] highlights the importance of argument characteristics, while [6-8] show that the source contributes in building trust online. Although attempts have been made to conduct individual research to identify the effects, it has been found that they cannot be isolated, but are mutually reinforcing in building trust. Ref. [9] propose and test an integrated online trust building model, starting from the model in [10] and the likelihood model in [11,12], and taking into account the key factors: argument, information and source. Refs. [11,13] experienced the quality of arguments and source expertise as key factors in determining the power of persuasion, and found that persuasion was stronger when the arguments were of good quality. The same result was obtained when the source submitting the arguments had a high level of expertise. The structural components of a good argument considered by the Toulmin model were: requirements, data, warranty, qualification, rebuttal, endorsement. Ref. [14] demonstrates that the essential components in argumentation are claims, data, and warranties. The Toulmin model is considered a useful way for determining the quality of the argumentation and the power of persuasion [15]. Refs. $[9,16,17]$ show that the mechanisms involved in the decision of a person to trust 
information on the Internet, in the health area, depend on the perception of its quality. The study demonstrates the significant intermediate role of the quality of information that leads to the generation of confidence and the decision of ordering the online medical product.

Buyers' behavior in the online environment is influenced by comments on customer experiences about goods. There are different types of messages and testimonials in the online environment [18-20]: audio, video, images and text. Opinions are based on personal experiences, but also on expert analysis and evaluation. The studies conducted by [21-23] show that some factors are decisive in generating the motivation to convey eWOM (electronic Word-of-Mouth): the consumer's need for social interaction, the strengthening of own values, and economic incentives. The same studies also demonstrated that the quality of the arguments is more attractive than the credibility of the eWOM source when someone decides to gather information about the product and then acquire it.

Interestingly, eWOM as a credible source of information refers to the expectations of those who receive it, to the ability of the person writing the message, and to their credibility, but says nothing about the information itself [24]. The eWOM information flow is expected to be fair and credible $[25,26]$. Information provided by professionals is believed to be trustworthy and motivates buying behavior [27]. However, not all information is provided by experts, and for this reason, refs. $[28,29]$ consider that evaluating the credibility of a message writer is very important. Ref. [30] describes this credibility from the point of view of honesty, non-involvement, and sufficient knowledge to evaluate the products.

The research conducted by [28] demonstrates that buyers are more focused on the quality of the arguments when they buy food. The majority opinion guides them. Because anyone can post online information, their quality cannot always be verified. Refs. [31,32] show that the readers appreciate the quality of the information precisely, the way of exposure and the opportunity/utility. The study made by [33] presents four fundamental characteristics of the information to be trusted: quality, understanding, reliability and utility. According to [34,35], consumers will only adopt those online reviews the use of which adds value.

Ref. [36] regarded the quality of the argument as essential, and the amount of reviews as secondary. The results of the study conducted by [37] showed that the quality of the argument and its perspectives both have positive effects on the perceived value and the adoption of online reviews as a final decision. The same study demonstrated, based on needs theory, that high-quality arguments cause consumers to be less susceptible to perspective arguments, considering them to have a positive effect on value.

Based on the considerations above, we formulated the following hypoyhesis:

Hypoyhesis (H1): There is a positive relationship between perceived argument quality and message credibility.

We expect that these relationships hold true for incentivized messages, but are significantly weaker. In other words, if the eWOM receivers know (or suspect) that the message transmitter was paid, they will be less inclined to trust it, even though the content seems to be accurate. Therefore, our research hypothesis is stated as follows:

Hypoyhesis $\left(\mathbf{H 1}^{\prime}\right)$ : The message type moderates the relationship between perceived argument quality and message credibility.

\subsection{Perceived Source Expertise}

The main effects of the marketing message source are considered to be effective when they positively influence the behavior of consumers and the way they communicate $[38,39]$.

A previous study [40] compares the impact of user-generated video clips (UVGs) as an informal source with agency-generated video clips (AGVs) as the official source, from the point of view of the credibility of the message sources and the generation of the intention to visit a promoted tourist location. Video quality was taken into consideration, and it was found that a poorer quality of UGVs resulted in a more positive impact on the credibility of the source, generating the intention to visit the tourist area, compared to AGVs. The 
classical literature studying the effects of the message source shows that the influence of the message communicated through a source close to the consumer has a greater effect on the buying behavior than an official source of an agency or expert [41].

Consumers receiving messages are more identified with noncommercial/informal sources because they understand them as more authentic, more realistic, similar to themselves $[42,43]$. Therefore, consumers' behavior is influenced by the messages sent by someone similar to them $[44,45]$. As a result of numerous studies, researchers have discovered the phenomenon that explains how information is disseminated over the Internet. This phenomenon is called homophily. Homophily is described as the degree to which individuals who interact with one another are similar in terms of certain attributes, such as: age, gender, ethnicity, and level of education [46]. Individuals with greater levels of interpersonal attraction and trust develop greater levels of emotional attachment [47]. Information exchange through WOM communication occurs more easily among homophilous individuals than among heterogeneous ones [48-50]. Homophily is the basis for the mass distribution of news. The higher the number of people who distribute the content, the more the user tends to believe, and then further distributes it to others. Social networks help empathize with people who think differently, but are effective in grouping them with those who share the same visions.

Ref. [51] propose a conceptual model that expands and tests the empirical model of [52] based on key components such as: homophily, contest of consumer websites, and tie strength. The goal is to reveal consumers' perceptions in their comments and purchase intent. Tie strength is defined as "the potency of the bond between members of a network" [53]. When people open links with certain websites/web pages, due to common shared interests, they tend to perceive reviews posted as more credible. The study in [51] demonstrated that tie strength and homophily about the web page accessed by the customer have improved the perception of the source credibility and the eWOM efficacy.

In conclusion, we devised the following hypothesis concerning the relationship between our variables:

Hypoyhesis (H2): There is a positive relationship between perceived source expertise and message credibility.

In addition, we expect that this relationship is significantly different for incentivized messages; even if the transmitter seems to be knowledgeable about the product, the message credibility will be lower if the reader knows that the sender was rewarded for writing it. Therefore, we propose the following hypothesis:

Hypoyhesis (H2'): The message type moderates the relationship between perceived source expertise and message credibility.

\subsection{Message Credibility}

Technology opportunities have been used by e-commerce managers to increase the amount of useful information to products and services buyers [54]. This information can be filtered to help potential buyers make a decision in a short time [55]. Many merchants have cultivated online review communities that provide reliable information [56]. Those who read digitized reviews have a higher level of satisfaction when their post-buying experience matches the recommendations they read online [57].

Ref. [58] developed one of the first eWOM credibility studies and indicated its multidimensional character, even indicating a theoretical model. Ref. [52] approaches credibility from a homophile perspective, with tie strength as the key variable in its assessment. The study conducted by [59] explains the concept of credibility from the perspective of eWOM anonymity, exclusively through the linguistic quality of consumer recommendations. Ref. [60] takes into account two factors that contribute to the credibility of eWOM: the power of the recommendation and its value related to the product. Ref. [61] analyzed technical issues when making credibility ratings. 
The credibility of the eWOM message and the acceptance of recommendations and reviews make the communication process successful $[62,63]$. To ensure the credibility of the message, the beneficiaries seek a safe source [64], which leads to a faster attitude and acceptance of the described product [65] and the adoption of information [66].

The study conducted by [66] shows that normative factors greatly influence the assessment of online recommendations. For this reason, the online reviewers use the aggregate rating as an indicator of credibility, but also of expertise and confidence. This aggregate assessment is based, in turn, on the recommendations of other consumers. The results of the study, based on moderate regression, show that there is a greater influence of expertise and homophily on the less involved people. Ref. [12] show that there are different information needs for the people who are involved a lot, who are attentive to the one who communicates, and carefully assess the message's credibility, and also try to find a high degree of homophily between the sender and the receiver of the information.

Organizations have become more and more interested in managing customer-tocustomer communication due to their high degree of credibility and persuasion, but also due to their easy accessibility. They used monetary stimulus for those who wanted to provide reviews. However, the reader has become circumspect about the truthfulness of reviews, and companies risk losing their credibility.

The study implemented by [67] puts the incentive program for reviews based on altruistic sources in the balance with stimulus programs based on monetary financing. A scenario-based experiment was used to compare the effects of incentives to generate eWOM and the confidence of readers. The stimulus was the donation, in order to overcome the perceived disadvantages. The results obtained showed that the reviews obtained through this incentive were trustworthy over the monetized ones, which were considered to be biased. The reviews obtained through other incentives brought a positive attitude towards the organization as compared to those that were monetized. The attribution of altruistic reasons to the recommender for writing the review is positively connected to both altruistic incentive programs. However, providing altruistic reasons for the organization in order to start the incentive program is not dependent on altruistic incentives. It is worth noting that consumers tend to look at companies with skepticism when they offer altruistic reasons for reviews, as consumers expect them to take an interest in maximizing profits [68].

We expect that people are less willing to act upon a paid eWOM message, even if they consider it credible, because if they did act, they would feel manipulated. People want disinterested product reviews and condemn the practice of using paid reviewers and influencers. Therefore, we believe that they "protest" against this practice by rejecting the incentivized reviews and recommendations (if they know that they are paid, of course). We propose the following research hypotheses:

Hypoyhesis (H3): There is a positive relationship between message credibility and intention to adopt eWOM.

Hypoyhesis $\left(\mathbf{H}^{\prime}\right)$ : The message type moderates the relationship between message credibility and intention to adopt eWOM.

\section{Instrument and Methodology}

To collect the necessary data, we used an online questionnaire applied to 398 subjects. Most of them were Romanian students and young professionals. A total of $72 \%$ of them were female subjects, and $28 \%$ were male subjects. Almost half of them $(43 \%)$ were in the $22-25$ age group, while $4 \%$ were in the $26-40$ age group. The vast majority of the respondents (96\%) use Facebook daily and $44 \%$ spend at least an hour a day on this social network.

To manipulate the message type variable, we created two instances of our questionnaire. Each instance started by presenting the respondents a Facebook post that reviewed and recommended a bicycle. The respondents were informed that the post author is a person with many years of experience in biking who had recently bought a new bicycle and 
was eager to talk about it online. The actual post content was the same in both instances (see Appendix A). However, in the second instance the potential respondents were made aware from the very beginning that they were seeing an incentivized post: the post author was paid to write and share it on Facebook. As for the post in the first instance, it was presented as being created by a genuine bike owner who had not been remunerated in any way for publishing that recommendation on Facebook.

The respondents were invited to read the Facebook post thoroughly and afterwards respond to a questionnaire. The items (questions) were the same in both instances.

The two questionnaire instances were uploaded on the Google Forms platform and the respondents were directed to them through an email link. This link activated a PHP script that operated as follows: the link to the first instance was presented to about half of the respondents, while the link to the second instance was shown to the other half. This way, the respondent sample was split at random into two groups: about fifty percent of them visited the first questionnaire, and fifty percent visited the second one. Each individual responder only saw one questionnaire instance, corresponding either to the paid or unpaid post.

The questionnaire itself was divided into four groups of questions. Each group measured a separate concept, namely: perceived argument quality (PAQ) of the messagenine questions; perceived source expertise (PSE)—five questions; message credibility_four questions; and intention to adopt the recommendation (i.e., intention to purchase the bicycle or recommend it to others) - five questions. The perceived argument quality and perceived source expertise inventory was adapted from [69]. For message credibility and adoption intention we have adapted the scale created by [60].

\section{Data Analysis}

\subsection{Scale Validation}

Before verifying our research hypotheses, we created our latent variables and then we tested them for reliability and validity. First, an exploratory factor analysis (EFA) was performed using the IBM SPSS Statistics software (version 21). The aim of this analysis was to identify the items that were weakly correlated with their latent factors. Only one item was removed at the end of the EFA (corresponding to the eWOM adoption construct), so 22 items were retained for the following stage. The KMO (Kaiser-Meier-Olkin) value for the EFA model was 0.953 and the Bartlett's test was statistically significant $(p<0.01)$, indicating an excellent sample adequacy.

To examine the hypothesized relationships between the latent constructs, we used structural equation modeling with the IBM Amos software, version 20. First of all, we performed a confirmatory factor analysis (CFA) to build our measurement model [70]. The cutoff values we employed to estimate the goodness-of-fit for this model were: for the comparative fit index (CFI) - 0.900; for the root mean square error of approximation (RMSEA)-0.08; for the Tuckey-Lewis index (TLI) - 0.900; for the goodness-of-fit index (GFI) - 0.800; for the adjusted goodness-of-fit index (AGFI) - 0.800; for the standardized root mean square residual (SRMR)-0.08; for the $\chi^{2} / \mathrm{df}$ ratio-between 1 and 5 . The latent constructs and the items that were included in the measurement model can be found in Table 1.

For each item, we reported the standardized path loading, as well as the $t$-test value and the standard error. For each latent variable, we reported the average variance extracted (AVE), the Cronbach's alpha and the composite reliability (CR).

The goodness-of-fit indicators of our measurement model have the following values: $\chi^{2}(200)=468.343, p<0.01, \chi^{2} / \mathrm{df}$ ratio-2.341, RMSEA-0.059, CFI-0.951, TLI-0.943, GFI-0.891, AGFI-0.862, SRMR-0.041. As can be seen, all the analyzed indicators meet the cutoff values, so we can conclude that our model is a very good fit. Furthermore, all standardized path loadings (coefficients) are greater than 0.500 , and all loadings are statistically significant $(t>1.96)$. More than this, the Cronbach's alpha values and the composite reliability indicators of all the latent variables are greater than 0.700 , suggesting 
a very good internal consistency. Finally, the average variance extracted of the constructs are greater than 0.500 , denoting a good convergent validity.

Table 1. Constructs and items.

\begin{tabular}{|c|c|c|c|c|c|c|}
\hline Constructs and Items & Beta & t-Value & SE & Alpha & $\begin{array}{l}\text { Composite } \\
\text { Reliability }\end{array}$ & AVE \\
\hline $\begin{array}{c}\text { Perceived argument quality (The information in this post } \\
\text { is ... ) }\end{array}$ & - & - & - & 0.904 & 0.895 & 0.662 \\
\hline Exact & 0.759 & - & - & - & - & - \\
\hline Complete & 0.747 & 17.439 & 0.058 & - & - & - \\
\hline Appropriate & 0.720 & 14.446 & 0.074 & - & - & - \\
\hline Relevant & 0.738 & 14.869 & 0.063 & - & - & - \\
\hline Valid & 0.728 & 14.642 & 0.063 & - & - & - \\
\hline Actual & 0.770 & 15.600 & 0.060 & - & - & - \\
\hline Timely & 0.633 & 12.544 & 0.062 & - & - & - \\
\hline Convincing & 0.685 & 13.678 & 0.065 & - & - & - \\
\hline Adequate & 0.616 & 12.181 & 0.067 & - & - & - \\
\hline Message credibility & - & - & - & 0.870 & 0.880 & 0.740 \\
\hline This post is credible. & 0.827 & - & - & - & - & - \\
\hline This post is reasonable. & 0.804 & 17.971 & 0.056 & - & - & - \\
\hline This post is sincere. & 0.741 & 16.120 & 0.059 & - & - & - \\
\hline This post is reliable. & 0.804 & 17.992 & 0.055 & - & - & - \\
\hline Source expertise (The person who posted this message ... ) & - & - & - & 0.864 & 0.874 & 0.717 \\
\hline Is an expert in bikes & 0.729 & - & - & - & - & - \\
\hline Has solid knowledge about bikes & 0.777 & 19.050 & 0.064 & - & - & - \\
\hline Is competent in bikes & 0.808 & 14.812 & 0.076 & - & - & - \\
\hline Is qualified to give advice about bikes & 0.682 & 12.615 & 0.079 & - & - & - \\
\hline Has experience with bikes & 0.700 & 12.944 & 0.076 & - & - & - \\
\hline eWOM adoption & - & - & - & 0.894 & 0.876 & 0.705 \\
\hline I would buy this bike based on this recommendation & 0.849 & - & - & - & - & - \\
\hline I would transmit this recommendation to others & 0.814 & 19.428 & 0.052 & - & - & - \\
\hline I would follow the advice in this recommendation & 0.857 & 21.008 & 0.045 & - & - & - \\
\hline This recommendation helps me make a decision easier & 0.791 & 18.597 & 0.048 & - & - & - \\
\hline
\end{tabular}

To validate the model, we assessed the discriminant validity of our model by comparing the squared correlations between our constructs with the average variance extracted (AVE). These figures can be examined in Table 2. The AVE values are shown in the main diagonal of the table (in bold), while the squared correlations can be found in the offdiagonal cells.

Table 2. Average variance extracted and construct squared correlations.

\begin{tabular}{ccccc}
\hline & $\begin{array}{c}\text { Perceived } \\
\text { Argument Quality }\end{array}$ & $\begin{array}{c}\text { Source } \\
\text { Expertise }\end{array}$ & $\begin{array}{c}\text { Message } \\
\text { Credibility }\end{array}$ & $\begin{array}{c}\text { eWom } \\
\text { Adoption }\end{array}$ \\
\hline Perceived argument quality & 0.662 & & & \\
Source expertise & 0.656 & 0.717 & & \\
Message credibility & 0.642 & 0.644 & 0.740 & \\
eWom adoption & 0.680 & 0.644 & 0.719 & 0.705 \\
\hline
\end{tabular}

Since most of the average variance extracted (AVE) values are greater than the squared correlations, we conclude that our measurement model shows good discriminant validity. Table 3 presents the mean, median and standard deviation of our latent constructs, in both groups of respondents (non-incentivized and incentivized post). 
Table 3. Means, medians and standard deviations of latent constructs.

\begin{tabular}{ccccccc}
\hline \multirow{2}{*}{ Construct } & \multicolumn{3}{c}{ Incentivized Message } & \multicolumn{2}{c}{ Non-Incentivized Message } \\
\cline { 2 - 7 } & Mean & Median & $\begin{array}{c}\text { Standard } \\
\text { Deviation }\end{array}$ & Mean & Median & $\begin{array}{c}\text { Standard } \\
\text { Deviation }\end{array}$ \\
\hline Perceived argument quality & 3.32 & 3.40 & 0.79 & 3.57 & 3.63 & 0.69 \\
Source expertise & 2.64 & 2.69 & 0.70 & 2.81 & 2.83 & 0.57 \\
Message credibility & 3.04 & 3.10 & 0.80 & 3.29 & 3.38 & 0.61 \\
eWom adoption & 3.10 & 3.13 & 0.95 & 3.40 & 3.49 & 0.84 \\
\hline
\end{tabular}

Furthermore, we conducted a measurement invariance test to establish whether our factor structure is equivalent for the two categories of the moderating variable: unincentivized and incentivized message, respectively. Assessing the measurement invariance was necessary before performing our multi-group analysis to test moderation. To execute the invariance test, we ran the CFA analysis in the two groups specified above, simultaneously and with no constraints (the coefficients were freely estimated in both groups). The goodness-of-fit indicators for this analysis are as follows: $\chi^{2}(400)=758.037, p<0.01, \chi^{2} / \mathrm{df}$ ratio-1.895, RMSEA-0.048, CFI-0.934, TLI-0.923, GFI-0.846, AGFI-0.805, SRMR0.054 . We got a very good model fit, so we can conclude that the groups are equivalent with regard to the factor structure.

The last stage of scale validation consisted of a confirmatory factor analysis executed separately in the two groups of interest, with the aim of testing our measurement model in each group. The values of the goodness-of-fit statistics in these groups can be inspected in Table 4.

Table 4. Goodness-of-fit indicators for the confirmatory factor analysis in each group.

\begin{tabular}{ccc}
\hline Indicator & Non-Incentivized Message & Non-Incentivized Message \\
\hline$\chi^{2}$ df ratio & 1.754 & 2.036 \\
RMSEA & 0.067 & 0.068 \\
SRMR & 0.054 & 0.048 \\
CFI & 0.925 & 0.939 \\
TLI & 0.913 & 0.929 \\
GFI & 0.836 & 0.853 \\
AGFI & 0.802 & 0.814 \\
\hline
\end{tabular}

As one can see, all the indicators meet the cutoff values in both groups. In consequence, our measurement scale is valid in both categories of the moderating variable.

\subsection{Hypothesis Testing}

To test the Hypotheses H1, H2 and H3, we developed and assessed the causal (or path) model presented in Figure 1, using the IBM Amos program, version 21.

The goodness-of-fit indicators of our proposed model are as follows: $\chi^{2}(202)=505.754$, $p<0.01, \chi^{2} / \mathrm{df}$ ratio-2.504, RMSEA-0.069, CFI-0.944, TLI-0.936, GFI-0.882, AGFI0.852 , SRMR - 0.049. Since all the indicators meet their cutoff values, our causal model is a good fit. The path coefficients for this model, in the whole sample, can be found in Figure 2 and Table 5.

It can be noticed that all coefficients are statistically significant; in consequence, $\mathrm{Hy}$ potheses $\mathrm{H} 1, \mathrm{H} 2$ and $\mathrm{H} 3$ are supported. 


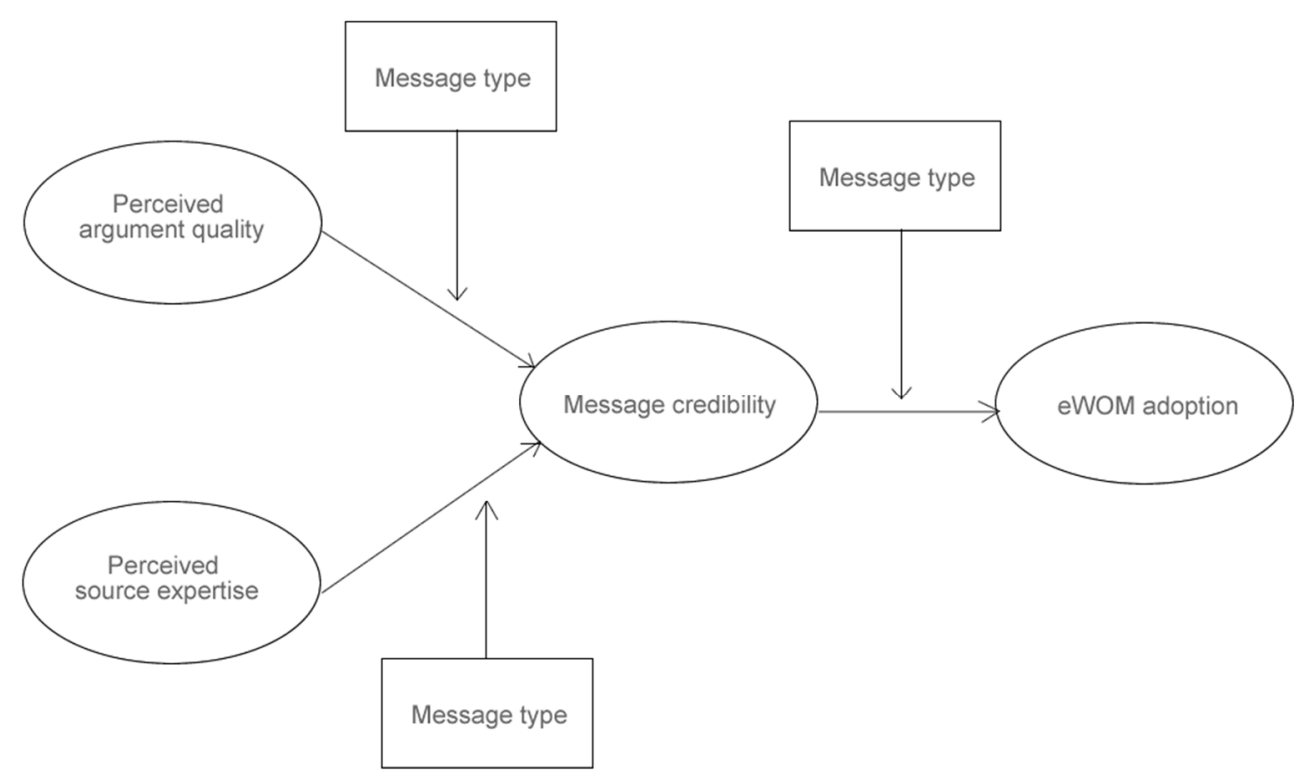

Figure 1. The causal model.

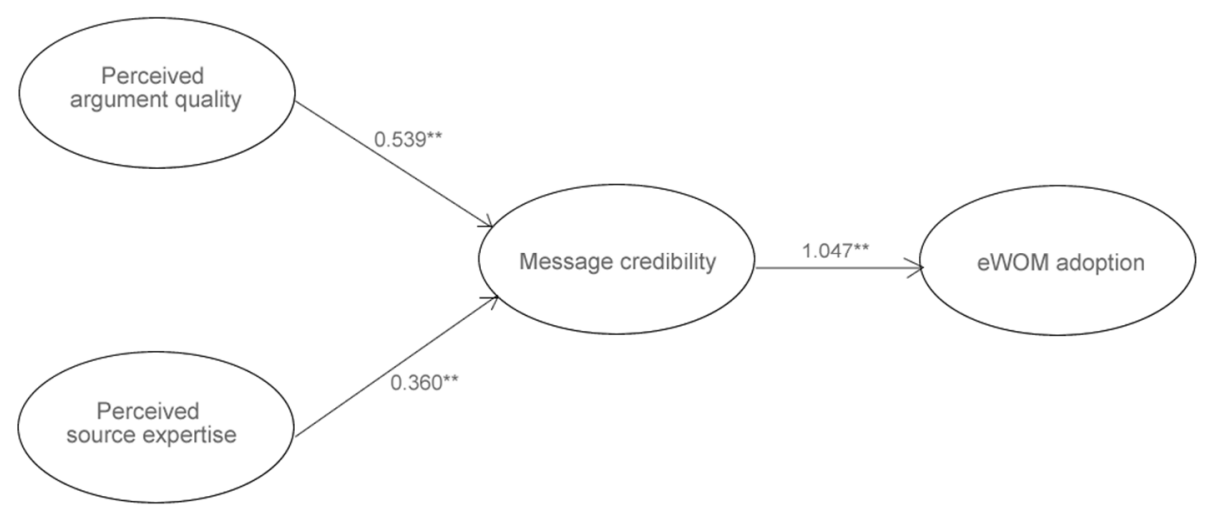

Figure 2. The path coefficients. ${ }^{* *}$ the coefficients marked by ** are significant at a 0.01 level.

Table 5. Causal model—path coefficients.

\begin{tabular}{ccccc}
\hline Hypothesis & \multicolumn{1}{c}{ Path } & Coefficient & $p$ & Result \\
\hline $\mathrm{H} 1$ & $\begin{array}{c}\text { Perceived argument quality } \\
\rightarrow \text { Message credibility } \\
\mathrm{H} 2\end{array}$ & $0.539\left(0.566^{*}\right)$ & $<0.001$ & Confirmed \\
$\mathrm{P}$ & $\begin{array}{c}\text { Perceived source expertise } \\
\rightarrow \text { Message credibility } \\
\mathrm{H} 3\end{array}$ & $0.360\left(0.328^{*}\right)$ & $<0.001$ & Confirmed \\
eWOMe credibility $\rightarrow$ & $1.047\left(0.828^{*}\right)$ & $<0.001$ & Confirmed \\
\hline${ }^{*}$ standardized coefficient value.
\end{tabular}

The next step of our research consisted of verifying the proposed Hypotheses $\mathrm{H}^{\prime}{ }^{\prime}, \mathrm{H} 2^{\prime}$, and $\mathrm{H}^{\prime}$, concerning the moderating variable type of message. To analyze the moderating effect in each model path, we used the multi-group CFA method described by [70]. First, we split our data set into two subsets based on the values of the moderating variable (non-incentivized and incentivized). For each subset, we created and estimated two causal models: the first one was a constrained model, and the second was an unconstrained model. In the second model, the value of the path of interest was set to value 1 . Next, we calculated the difference in Chi-square between the constrained and unconstrained model. If this difference was greater than 3.84 (the Chi-square value for one degree of freedom) in both subsets, we concluded that the moderating effect in that path was statistically significant. 
Therefore, we built and assessed six causal models in total, two for each path of the model in Figure 1. Hereinafter we present the results of the analysis in each model path.

The results of the moderation tests for the relationship between perceived argument quality and message credibility are displayed in Table 6.

Table 6. Moderation test of the message type in the relationship between perceived argument quality and message credibility.

\begin{tabular}{|c|c|c|c|c|c|}
\hline \multicolumn{6}{|c|}{ Non-Incentivized Message } \\
\hline & $\begin{array}{l}\text { Constrained } \\
\text { Model }\end{array}$ & $\begin{array}{c}\text { Unconstrained } \\
\text { Model }\end{array}$ & $\begin{array}{l}\text { Chi-square } \\
\text { Difference }\end{array}$ & $\begin{array}{l}\text { Result on } \\
\text { Moderation }\end{array}$ & $\begin{array}{c}\text { Result on } \\
\text { Hypothesis } \mathrm{H1}^{\prime}\end{array}$ \\
\hline Chi-square & 411.104 & 389.306 & 21.798 & Significant & Supported \\
\hline DF & 203 & 202 & 1 & & \\
\hline \multicolumn{6}{|c|}{ Incentivized message } \\
\hline & $\begin{array}{l}\text { Constrained } \\
\text { Model }\end{array}$ & $\begin{array}{c}\text { Unconstrained } \\
\text { Model }\end{array}$ & $\begin{array}{l}\text { Chi-square } \\
\text { Difference }\end{array}$ & $\begin{array}{l}\text { Result on } \\
\text { Moderation }\end{array}$ & $\begin{array}{c}\text { Result on } \\
\text { Hypothesis } \mathrm{H1}^{\prime}\end{array}$ \\
\hline Chi-square & 431.368 & 415.961 & 15.407 & Significant & Supported \\
\hline DF & 203 & 202 & 1 & & \\
\hline
\end{tabular}

The difference in Chi-square between the unconstrained and constrained model is greater than 3.84 in both groups, so the moderation effect is significant in this path. Consequently, Hypothesis $\mathrm{H}^{\prime}$ is supported.

Table 7 presents the results of the moderation tests for the next path in the model, the relationship between perceived source expertise and message credibility. Hypothesis $\mathrm{H}^{\prime}$ is supported because the difference in Chi-square between the models is greater than 3.84 in both groups.

Table 7. Moderation test of the message type in the relationship between perceived source expertise and message credibility.

\begin{tabular}{|c|c|c|c|c|c|}
\hline \multicolumn{6}{|c|}{ Non-Incentivized Message } \\
\hline & $\begin{array}{c}\text { Constrained } \\
\text { Model }\end{array}$ & $\begin{array}{c}\text { Unconstrained } \\
\text { Model }\end{array}$ & $\begin{array}{l}\text { Chi-square } \\
\text { Difference }\end{array}$ & $\begin{array}{l}\text { Result on } \\
\text { Moderation }\end{array}$ & $\begin{array}{c}\text { Result on } \\
\text { Hypothesis H2' }\end{array}$ \\
\hline Chi-square & 411.368 & 389.306 & 22.062 & Significant & Supported \\
\hline DF & 203 & 202 & 1 & & \\
\hline \multicolumn{6}{|c|}{ Incentivized message } \\
\hline & $\begin{array}{l}\text { Constrained } \\
\text { Model }\end{array}$ & $\begin{array}{c}\text { Unconstrained } \\
\text { Model }\end{array}$ & $\begin{array}{l}\text { Chi-square } \\
\text { Difference }\end{array}$ & $\begin{array}{l}\text { Result on } \\
\text { Moderation }\end{array}$ & $\begin{array}{c}\text { Result on } \\
\text { Hypothesis } \mathrm{H}^{\prime}\end{array}$ \\
\hline Chi-square & 433.426 & 415.961 & 17.465 & Significant & Supported \\
\hline DF & 203 & 202 & 1 & & \\
\hline
\end{tabular}

Finally, Table 8 displays the results of the moderation tests for the last paths, the relationship between message credibility and intention to adopt eWOM. The difference in Chi-square between the models is smaller than 3.84 in both groups (incentivized and nonincentivized message), so the moderation effect is not statistically significant in this path. 
Table 8. Moderation test of the message type in the relationship between perceived source expertise and message credibility.

\begin{tabular}{|c|c|c|c|c|c|}
\hline \multicolumn{6}{|c|}{ Non-Incentivized Message } \\
\hline & $\begin{array}{l}\text { Constrained } \\
\text { Model }\end{array}$ & $\begin{array}{c}\text { Unconstrained } \\
\text { Model }\end{array}$ & $\begin{array}{l}\text { Chi-square } \\
\text { Difference }\end{array}$ & $\begin{array}{l}\text { Result on } \\
\text { Moderation }\end{array}$ & $\begin{array}{c}\text { Result on } \\
\text { Hypothesis } \mathrm{H}^{\prime}\end{array}$ \\
\hline Chi-square & 392.783 & 389.306 & 3.477 & Not significant & Not supported \\
\hline DF & 203 & 202 & 1 & & \\
\hline \multicolumn{6}{|c|}{ Incentivized message } \\
\hline & $\begin{array}{l}\text { Constrained } \\
\text { Model }\end{array}$ & $\begin{array}{c}\text { Unconstrained } \\
\text { Model }\end{array}$ & $\begin{array}{l}\text { Chi-square } \\
\text { Difference }\end{array}$ & $\begin{array}{l}\text { Result on } \\
\text { Moderation }\end{array}$ & $\begin{array}{c}\text { Result on } \\
\text { Hypothesis } \mathrm{H}^{\prime}\end{array}$ \\
\hline Chi-square & 416.039 & 415.961 & 0.978 & Not significant & Not supported \\
\hline DF & 203 & 202 & 1 & & \\
\hline
\end{tabular}

In consequence, the relationship between message credibility and eWOM adoption is not moderated by the message type (Hypothesis $\mathrm{H}^{\prime}$ is not valid).

The path coefficients for each message type are presented in Table 9.

Table 9. Path coefficients for each group (message type).

\begin{tabular}{ccccc}
\hline & Non-Incentivized Message & \multicolumn{2}{c}{ Incentivized Message } \\
\hline & Coefficient & $\boldsymbol{p}$ & Coefficient & $\boldsymbol{p}$ \\
\hline Perceived argument quality $\rightarrow$ Message credibility & $0.449\left(0.587^{*}\right)$ & $<0.01$ & $0.535\left(0.596^{*}\right)$ & $<0.01$ \\
Perceived source expertise $\rightarrow$ Message credibility & $0.337\left(0.360^{*}\right)$ & $<0.01$ & $0.396\left(0.424^{*}\right)$ & $<0.01$ \\
Message credibility $\rightarrow$ eWOM adoption & $1.263\left(0.853^{*}\right)$ & $<0.01$ & $0.978\left(0.813^{*}\right)$ & $<0.01$ \\
\hline
\end{tabular}

${ }^{*}$ standardized coefficient value.

We can notice that the relationship between perceived argument quality and perceived source expertise, on the one hand, and credibility, on the other hand, is more pronounced for the incentivized message. All these results will be discussed in the following section of this paper.

\section{Discussion}

Our findings confirm the hypotheses regarding the relationship between the attributes of the message (argument quality and source expertise) and message credibility. The positive relationship between perceived argument quality and message credibility was proved by $[37,66,71]$, while the positive relationship between perceived source expertise and credibility was verified by $[2,72,73]$. The conclusions of the above-mentioned authors are supported by our study: there is a positive relationship between argument quality and credibility, one the one hand, and between source expertise and credibility, on the other hand. Furthermore, we found a significant positive relationship between message credibility and eWOM adoption intention. This result is consistent with the results obtained by [37].

Our research also explores the moderating role of the message type (incentivized vs. non-incentivized) in the relationships above. This represents the most important contribution of our paper: explaining how the message type affects the eWOM impact on the receiver. This issue is insufficiently treated in the papers that look into incentivized eWOM. The vast majority of these papers (like [74,75] or [76]) focus on how stimulation programs increase product recommendation likelihood. In other words, these researchers treat incentives-either monetary or non-monetary-as eWOM triggers (people talk about products because they are rewarded in some way). They study the effects of incentives on eWOM communicators. Our approach here is entirely different: we examine the influence of incentivized messages on eWOM receivers. More specifically, we analyze how message type (paid or genuine) interferes in the relationship between message attributes, message 
credibility and recipient's behavior (their intention of acting upon the message or not). Our purpose was to prove that the intensity of these relationships changes significantly when the recipient knows (or just presumes) that the transmitter was remunerated for writing the message.

As our results show, the message type significantly moderates the relationship between perceived argument quality and credibility $\left(\mathrm{H}_{1}^{\prime}\right.$ and $\left.\mathrm{H} 2^{\prime}\right)$. In Table 9, we can notice that the path coefficient is greater for the incentivized message, so the influence of the argument quality on credibility is stronger in this group. In conclusion, though perceived argument quality is a good predictor of credibility for both message types, it is more important in the case of incentivized messages. People can give enough trust to disinterested eWOM messages even if the quality of information is not too great. If they know (or presume) that the eWOM transmitter is remunerated, they will pay more attention to the actual message content. If they perceive this content as being accurate and relevant, their confidence will increase substantially. However, if the message's arguments are weak and specious, its credibility will drop significantly. Therefore, paid eWOM messages stand a chance of being persuasive only if they contain high-quality arguments; otherwise they will be deemed to be biased and unconvincing.

Message type is also a significant moderator of the relationship between perceived source expertise and credibility. As seen in Table 9, perceived source expertise has a stronger impact on credibility (H2) in the case of incentivized messages ( $\mathrm{H}_{2}^{\prime}$ - the path coefficient is slightly greater). As a consequence, the eWOM receiver will only trust a remunerated message if the transmitter proves that he is highly qualified to give recommendation for that product or service. If they are not perceived as a true expert, the message credibility plummets. On the other hand, non-incentivized messages can have a satisfactory level of credibility even if the perceived source expertise is relatively low.

As a conclusion, perceived argument quality and source expertise (H1 and H2) influence message credibility irrespective of the message type (paid or unpaid). However, these two attributes are decisive if the eWOM receiver knows that they are dealing with an incentivized recommendation (H3).

Furthermore, our findings show that the type of message does not moderate the relationship between message credibility and eWOM adoption intention $\left(\mathrm{H}^{\prime}\right)$. If the reader perceives the message as being trustworthy, the chances of buying the product or recommending it to other people increase, no matter whether the message is incentivized or not. In conclusion, the real challenge of the eWOM spreaders is to create and distribute high-relevance, persuasive messages. If messages are credible, receivers will likely act upon them, even if they believe that their authors were remunerated or rewarded in some form.

From a managerial perspective, the results we obtained from the scientific research we conducted lead us to say that consumer perceptions vary depending on the two distinct situations: incentivized recommendations and non-incentivized recommendations.

From the merchant's point of view, it is very important to be aware that paid recommendations can persuade consumers to buy only if the quality of the content is impeccable and if the recommendations come from someone you trust.

As a result, in order for online marketing campaigns to be successful, marketing managers must take into account this information highlighted by our research. Otherwise, the marketing budget may be wasted on promotional efforts that will not achieve their desired goal.

\section{Limitations and Future Research}

In using the results of this research, we should be aware that it has several limitations. In the first place, only Romanian subjects were included in the sample, most of them young (because young people are the most fervent social network users). Another limitation is the fact that we have used the convenience sampling method. These limitations may reduce to some extent the generalization of our studies. Moreover, our research is limited 
to one category of physical product only-bicycles. Future studies could examine the impact of independent and incentivized eWOM for other products category, as well as for services and online stores. Additionally, further research should take into consideration other constructs that may influence the intention of adoption for the incentivized eWOM messages. Examples of these constructs could be familiarity with the brand, pre-existing attitude towards the company or brand, perceived similarity to the reviewer (homophily), and so on. Another possible research direction consists of investigating the perception about the incentivized eWOM in general, and how this perception influences credibility and propensity to adopt the incentivized eWOM messages.

\section{Conclusions}

The most significant conclusion of our research is that message type (paid or not paid) affects the impact of message attributes on message credibility. More specifically, credibility antecedents have a stronger impact in the case of incentivized messages. To be judged as believable, the content of these messages should be particularly relevant and convincing. Additionally, the message transmitter should be renowned (or at least perceived) as an expert in the field-a person who is qualified to evaluate the product and give advice to other potential buyers. A genuine, disinterested eWOM message has chances to be trusted even if argument quality is weaker and perceived source expertise is lower, because it is seen as authentic and spontaneous. However, things are different for rewarded messages. Here, any drop in quality and source authority will lead to a substantial decrease of message trustworthiness.

Furthermore, trustworthiness directly affects receiver's behavior-intention to adopt eWOM. In this relationship, message type does not have a significant moderating effect. In conclusion, a credible message will likely generate an action from the part of the receiver, no matter if it is incentivized or not. This action can be either buying the product or sharing the message to other people. Though conventional wisdom might think that people only follow disinterested advice, our results show that social media users are oftentimes willing to adhere to recommendations that come from remunerated sources, if they consider them reliable.

To sum up, our paper provides insights on how knowing that a Facebook recommendation is incentivized (paid) alters the readers' perceptions on the recommendation credibility, as well as their behavior-acting upon the recommendation and purchasing the product. Paid recommendations can actually be effective (convince people to buy), but only if two essential conditions are satisfied: they come from a highly trusted sender and their content quality and relevancy is impeccable. These conditions are important for a non-incentivized message as well, but for a paid one they are key imperatives. If they are not met, the message credibility will drop substantially, and so will the probability that the receiver follows the advice in the message.

The results of our research also have some practical implications. It is not recommended for companies to hire and use paid reviewers on a regular basis. If the customers become aware of this fact, their trust in the company and its products could plunge, because of the lower credibility of the incentivized reviews. Occasionally, the company could entice some of its happy customers to leave positive reviews and comments, if they are really satisfied with the product and consent to talk about it in the online environment. Even if these customers are compensated in some way for their effort, their reviews remain honest, authentic, and therefore trustworthy.

Author Contributions: Conceptualization, B.A. and N.D.; methodology, B.A. and O.D.; software, B.A.; validation, N.D. and O.D.; formal analysis, B.A. and N.D.; investigation, B.A., N.D. and O.D.; resources, O.D.; data curation, N.D.; writing-original draft preparation, B.A. and N.D.; writingreview and editing, N.D. and O.D. All authors have read and agreed to the published version of the manuscript.

Funding: This research received no external funding. 
Institutional Review Board Statement: Not applicable.

Informed Consent Statement: Not applicable.

Data Availability Statement: The data used in this study are available on request from B.A.

Conflicts of Interest: The authors declare no conflict of interest.

\section{Appendix A. The Content of the Post That Was Presented to the Respondents}

It is a high quality bike, it was worth the price paid on it. I've had it for half a year and it did not cause me any trouble. It is also very easy to assemble, the instructions are clear (in fact, you almost do not need instructions). It does not weigh much, the seat is comfortable and the brakes work perfectly. The frame is robust, very well worked out. The gearboxes seemed a bit difficult to maneuver at first, because I wasn't used to them, but now I switch gears easier than on my old bike. In addition, it looks very good and it is a pleasure to ride it. I went with it in the city, but also on longer routes, with average difficulty. Therefore, if you want a good bike and do not have much money, I advise you to buy this one.

\section{References}

1. Boerman, S.; Willemsen, L.; van der Aa, E. "This post is sponsored": Effects of sponsorship disclosure on persuasion knowledge and electronic word of mouth in the context of Facebook. J. Interact. Mark. 2017, 38, 82-92. [CrossRef]

2. Cheung, C.; Lee, M.; Rabjohn, N. The impact of electronic word-of-mouth: The adoption of online opinions in online customer communities. Internet Res. 2008, 18, 229-247. [CrossRef]

3. Hussain, S.; Guangju, W.; Jafar, R.; Ilyas, Z.; Mustafa, G.; Jianzhou, Y. Consumers' online information adoption behavior: Motives and antecedents of electronic word of mouth communications. Comput. Hum. Behav. 2018, 80, 22-32. [CrossRef]

4. López, M.; Sicilia, M. Determinants of E-WOM influence: The role of consumers' internet experience. J. Theor. Appl. Electron. Commer. Res. 2014, 9, 28-43. [CrossRef]

5. Kim, K.D.; Benbasat, I. Trust-assuring arguments in b2c e-commerce: Impact of content, source, and price on trust. J. Ofmanagement Inf. Syst. 2009, 26, 175-206. [CrossRef]

6. Nooteboom, B.; Berger, H.; Noorderhaven, N. Effects of trust and governance on relational risk. Acad. Manag. J. 1997, 40, 308-338.

7. Song, J.; Zahedi, F. Trust in health infomediaries. Decis. Support. Syst. 2007, 43, 390-407. [CrossRef]

8. Chetioui, Y.; Lebdaoui, H.; Chetioui, H. Factors influencing consumer attitudes toward online shopping: The mediating effect of trust. EuroMed J. Bus. 2020. [CrossRef]

9. Yi, M.; Yoon, J.; Davis, J.; Lee, T. Untangling the antecedents of initial trust in Web-based health information: The roles of argument quality, source expertise, and user perceptions of information quality and risk. Decis. Support. Syst. $2013,55,284-295$. [CrossRef]

10. Toulmin, S. The Uses of Arguments; University Press: Cambridge, UK, 1958.

11. Petty, R.; Cacioppo, J. Attitudes and Persuasion: Classic and Contemporary Approaches; William C Brown: Dubuque, IA, USA, 1981.

12. Petty, R.; Cacioppo, J. The elaboration likelihood model of persuasion. In Advances in Experimental Social Psychology; Academic Press: San Diego, CA, USA, 1986; pp. 123-205.

13. Capkinoglu, E.; Yilmaz, S.; Leblebicioglu, G. Quality of argumentation by seventh-graders in local socioscientific issues. J. Res. Sci. Teach. 2020, 57, 827-855. [CrossRef]

14. Ye, L.; Johnson, P. The impact of explanation facilities on user acceptance of expert-systems advice. MIS Q. 1995, 19, 157-172. [CrossRef]

15. Boller, G.; Swasy, J.; Munch, J. Conceptualizing argument quality via argument structure. Adv. Consum. Res. 1990, 17, 321-328.

16. Seckin, G.; Campbell, P.; Lawson, M. Digital Health Information as Friend or Foe: The Question of (Mis)Trust Among Older Internet Users. Innov. Aging 2020, 4, 410. [CrossRef]

17. Daraz, L.; Morrow, A.; Ponce, O. Can Patients Trust Online Health Information? A Meta-narrative Systematic Review Addressing the Quality of Health Information on the Internet. J. Gen. Intern. Med. 2019, 34, 1884-1891. [CrossRef] [PubMed]

18. Rosario, A.B.; de Valck, K.; Sotgiu, F. Conceptualizing the electronic word-of-mouth process: What we know and need to know about eWOM creation, exposure, and evaluation. J. Acad. Mark. Sci. 2020, 48, 422-448. [CrossRef]

19. Buraga, S.C.; Dospinescu, O. A Knowledge-Based Pilot Study on Assessing the Music Influence. Comput. Mater. Contin. 2021, 66, 2857-2873. [CrossRef]

20. Zhao, P.; Wu, J.; Hua, Z.; Fang, S. Finding eWOM customers from customer reviews. Ind. Manag. Data Syst. 2019, 119, 129-147. [CrossRef]

21. Martin, W.C. Independent Versus Incentivized Word-of-Mouth: Effects on Listeners. Acad. Mark. Study J. 2015, $19,1-11$.

22. Ismagilova, E.; Rana, N.; Slade, E.; Dwivedi, Y. A meta-analysis of the factors affecting eWOM providing behaviour. Eur. J. Mark. 2020, 20. [CrossRef] 
23. Hussain, S.; Song, X.; Niu, B. Consumers' Motivational Involvement in eWOM for Information Adoption: The Mediating Role of Organizational Motives. Front. Psychol. 2020, 10, 3055. [CrossRef]

24. Luo, C.; Luo, X.; Schatzberg, L.; Sia, C. Impact of informational factors on online recommendation credibility: The moderating role of source credibility. Decis. Support. Syst. 2013, 56, 92-102. [CrossRef]

25. Yoo, C.; Sanders, G.; Moon, J. Exploring the effect of e-WOM participation on e-Loyalty in e-commerce. Decis. Support. Syst. 2013, 55, 669-678. [CrossRef]

26. Le-Hoang, P.V. The effects of Electronic Word of Mouth (eWOM) on the adoption of consumer eWOM information. Indep. J. Manag. Prod. 2020, 11, 1749-1766. [CrossRef]

27. Tormala, Z.; Petty, R. Source credibility and attitude certainty: A metacognitive analysis of resistance to persuasion. J. Consum. Psychol. 2004, 14, 427-442. [CrossRef]

28. Hussain, S.; Ahmed, W.; Jafar, R.; Rabnawaz, A.; Jianzhou, Y. eWOM source credibility, perceived risk and food product customer's information adoption. Comput. Hum. Behav. 2017, 66, 96-102. [CrossRef]

29. Ismagilova, E.; Slade, E.; Rana, N.; Dwivedi, Y. The effect of characteristics of source credibility on consumer behaviour: A meta-analysis. J. Retail. Consum. Serv. 2020, 53. [CrossRef]

30. O'Keefe, D. Persuasion: Theory and Research, 2nd ed.; SAGE Publications: Thousand Oaks, CA, USA, 2002.

31. Suh, M.; Greene, H.; Israilov, B.; Rho, T. The impact of customer education on customer loyalty through service quality. Serv. Mark. Q. 2015, 36, 261-280. [CrossRef]

32. Wallace, L.; Wegener, D.; Petty, R. Consuming Information from Sources Perceived as Biased versus Untrustworthy: Parallel and Distinct Influences. J. Assoc. Consum. Res. 2020, 5, 1-32. [CrossRef]

33. Wu, L. The antecedents of customer satisfaction and its link to complaint intentions in online shopping: An integration of justice, technology, and trust. Int. J. Inf. Manag. 2013, 33, 166-176. [CrossRef]

34. Scherer, A.; Wunderlich, N.; Wangenheim, F. The value of self-service: Long-term effects of technology-based self-service usage on customer retention. MIS Q. 2015, 39, 177-200. [CrossRef]

35. Lo, A.; Yao, S. What makes hotel online reviews credible? An investigation of the roles of reviewer expertise, review rating consistency and review valence. Int. J. Contemp. Hosp. Manag. 2019, 31, 41-60. [CrossRef]

36. Zhang, K.; Zhao, S.; Cheung, C.; Lee, M. Examining the influence of online reviews on consumers' decision-making: A heuristicsystematic model. Decis. Support. Syst. 2014, 67, 78-89. [CrossRef]

37. Xi, X.; Zhong, Y. Understanding the role of argument quality in the adoption of online reviews. Online Inf. Rev. 2015, 39, 885-902.

38. Hennig-Thurau, T.; Walsh, G. Electronic word of mouth: Motives for and consequences of reading customer articulations on the Internet. Int. J. Electron. Commer. 2004, 8, 51-74. [CrossRef]

39. van Noort, G.; Voorveld, H.; van Reijmersdal, E. Interactivity in Brand Web Sites: Cognitive, Affective, and Behavioral Responses Explained by Consumers' Online Flow Experience. J. Interact. Mark. 2012, 26, 223-234. [CrossRef]

40. Hautz, J.; Füller, J.; Hutter, K.; Thürridl, C. Let Users Generate Your Video Ads? The Impact of Video Source and Quality on Consumers' Perceptions and Intended Behaviors. J. Interact. Mark. 2014, 28, 1-15. [CrossRef]

41. Andsager, J.; Bemker, V.; Hong-Lim, C.; Torwel, V. Perceived Similarity of Exemplar Traits and Behavior: Effects on Message Evaluation. Commun. Res. 2006, 33, 3-18. [CrossRef]

42. Chakravarty, A.; Yong, L.; Tridib, M. The Differential Effects of Online Word-of-Mouth and Critics' Reviews on Pre-Release Movie Evaluation. J. Interact. Mark. 2010, 24, 185-197. [CrossRef]

43. Daowd, A.; Hasan, R.; Eldabi, T.; Rafi-ul-Shan, P.; Cao, D.; Kasemsarn, N. Factors affecting eWOM credibility, information adoption and purchase intention on Generation Y: A case from Thailand. J. Enterp. Inf. Manag. 2020, 1-12. [CrossRef]

44. Moscovici, S. Social Influence and Conformity. In Handbook of Social Psychology: Special Fields and Applications; Random House: New York, NY, USA, 1985; pp. 341-412.

45. Vitaloka, N.M.D.W.; Alversia, Y. Identifying Aspects Toward Ewom Credibility and Source of Trustworthiness. Glob. J. Bus. Soc. Sci. Rev. 2019, 7, 166-177. [CrossRef]

46. Rogers, E. Diffusion of Innovations; Collier MacMillan Publishers: New York, NY, USA, 1983.

47. Hyun, S.; Kim, I. Identifying optimal rapport-building behaviors in inducing patrons' emotional attachment in luxury restaurants. J. Hosp. Tour. Res. 2014, 38, 162-198. [CrossRef]

48. Brown, J.; Reingen, P. Social ties and word-of-mouth referral behavior. J. Consum. Res. 1987, 14, 350-362. [CrossRef]

49. Chu, S.; Kim, Y. Determinants of customer engagement in electronic word-of-mouth (eWOM) in social networking sites. Int. J. Advert. 2011, 30, 47-75. [CrossRef]

50. Zhang, H.; Liang, X.; Qi, C. Investigating the impact of interpersonal closeness and social status on electronic word-of-mouth effectiveness. J. Bus. Res. 2020, 1-9. [CrossRef]

51. Kim, S.; Kandampully, J.; Bilgihan, A. The influence of eWOM communications: An application of online social network framework. Comput. Hum. Behav. 2018, 80, 243-254. [CrossRef]

52. Brown, J.; Broderick, A.; Lee, N. Word of mouth communication within online communities: Conceptualizing the online social network. J. Interact. Mark. 2007, 21, 2-20. [CrossRef]

53. Mittal, V.; Huppertz, J.; Khare, A. Customer complaining: The role of tie strength and information control. J. Retail. 2008, 84, 195-204. [CrossRef]

54. Zwass, V. Editor's introduction. Int. J. Electron. Commer. 2012, 17, 5-10. [CrossRef] 
55. Hennig-Thurau, T.; Gwinner, K.; Walsh, G.; Gremler, D. Electronic Word-of-Mouth Via Consumer-Opinion Platforms: What Motivates Consumers to Articulate Themselves on the Internet? J. Interact. Mark. 2004, 18, 38-52. [CrossRef]

56. Chen, P.; Dhanasobhon, S.; Michael, S. All reviews are not created equal: The disaggregate impact of reviews and reviewers at Amazon.com. SSNR 2008. [CrossRef]

57. Sormunen, V. International Viral Marketing Campaign Planning and Evaluation; Aalto University Learning Center: Espoo, Finland, 2009.

58. Wathen, C.; Burkell, J. Believe it or not: Factors influencing credibility on the web. J. Am. Soc. Inf. Sci. Technol. 2002, 53, 134-144. [CrossRef]

59. Mackiewicz, J. Reviewer motivations, bias, and credibility in online reviews. In Handbook of Research on Computer Mediated Communication; ICI Global: Hershey, PA, USA, 2008; pp. 252-266.

60. Cheung, M.; Luo, C.; Sia, C.; Chen, H. Credibility of electronic word-of-mouth: Informational and normative determinants of on-line consumer recommendations. Int. J. Electron. Commer. 2009, 13, 9-38. [CrossRef]

61. O'Reilly, K.; Marx, S. How young technical consumers assess online WOM credibility. Qual. Mark. Res. Int. J. 2011, 14, 330-359. [CrossRef]

62. Sussman, S.; Siegal, W. Informational influence in organizations: An integrated approach to knowledge adoption. Inf. Syst. Res. 2003, 14, 47-65. [CrossRef]

63. Ngarmwongnoi, C.; Oliveira, J.; AbedRabbo, M.; Mousavi, S. The implications of eWOM adoption on the customer journey. J. Consum. Mark. 2020, 37, 749-759. [CrossRef]

64. Petty, R.; Priester, J.; Brinol, P. Mass media attitude change: Implications of the elaboration likelihood model of persuasion. In Media Effects: Advances in Theory and Research; Lawrence Erlbaum: Mahwah, NJ, USA, 2002; pp. 155-198.

65. Hu, N.; Liu, L.; Zhang, J. Do online reviews affect product sales? The role of reviewer characteristics and temporal effects. Inf. Technol. Manag. 2008, 9, 201-214. [CrossRef]

66. Lis, B. In eWOM We Trust-A Framework of Factors that Determine the eWOM Credibility. Bus. Inf. Syst. Eng. 2013, 5, 129-140. [CrossRef]

67. Reimer, T.; Benkenstein, M. Not just for the recommender: How eWOM incentives influence the recommendation audience. J. Bus. Res. 2018, 86, 11-21. [CrossRef]

68. Ellen, P.; Webb, D.; Mohr, L. Building corporate associations: Consumer attributions for corporate socially responsible programs. J. Acad. Mark. Sci. 2006, 34, 147-157. [CrossRef]

69. Ohanian, R. Construction and validation of a scale to measure celebrity endorsers' perceived expertise, trustworthiness and attractiveness. J. Advert. 1990, 19, 39-52. [CrossRef]

70. Awang, Z. A Handbook on Structural Equation Modeling Using Amos; Universiti Technologi MARA Press: Kuala Lumpur, Malaysia, 2012.

71. Teng, S.; Kok, W.; Goh, W.; Chong, A. Examining the antecedents of persuasive eWOM messages in social media. Online Inf. Rev. 2014, 38, 746-768. [CrossRef]

72. Schouten, A.; Janssen, L.; Verspaget, M. Celebrity vs. Influencer endorsements in advertising: The role of identification, credibility, and Product-Endorser fit. Int. J. Advert. 2019, 39, 258-281. [CrossRef]

73. Fan, Y.; Miao, Y.; Fang, Y.; Lin, R. Establishing the adoption of electronic word-of-mouth through consumers perceived credibility. Int. Bus. Res. 2013, 6, 58-65. [CrossRef]

74. Kim, J.; Naylor, G.; Sivadas, E.; Sugumaran, V. The unrealized value of incentivized eWOM recommendations. Mark. Lett. 2016, 27, 411-421. [CrossRef]

75. Reimer, T.; Benkenstein, M. Altruistic eWOM marketing: More than an alternative to monetary incentives. J. Retail. Consum. Serv. 2016, 31, 323-333. [CrossRef]

76. Rehnen, L.-M.; Bartsch, S.; Kull, M.; Meyer, A. Exploring the impact of rewarded social media engagement in loyalty programs. J. Serv. Manag. 2017, 28, 305-328. [CrossRef] 